\title{
Refractory Desmoplastic Small Round Cell Tumor
}

National Cancer Institute

\section{Source}

National Cancer Institute. Refractory Desmoplastic Small Round Cell Tumor. NCI

Thesaurus. Code C158427.

Desmoplastic small round cell tumor that is resistant to treatment. 